\title{
Analyzing genomes: is there a duty to disclose?
}

Amy McGuire

From Beyond the Genome 2012

Boston, MA, USA. 27-29 September 2012

The potential to discover unanticipated clinically significant genetic variants during the course of research has stimulated much debate about the obligations of researchers to communicate such findings to study participants. Published guidelines suggest that researchers have an obligation to communicate valid and significant results, especially if they are clinically actionable. I will present data on the practices and perspectives of investigators conducting genome-wide association studies (GWAS) and will caution against the establishment of a general obligation to return results in research. I will compare the role-specific responsibilities of researchers with those of clinicians and discuss emerging standards for genomic analysis and communication of test results in the clinical setting.

Published: 1 October 2012

Submit your next manuscript to BioMed Central and take full advantage of:

- Convenient online submission

- Thorough peer review

- No space constraints or color figure charges

- Immediate publication on acceptance

- Inclusion in PubMed, CAS, Scopus and Google Scholar

- Research which is freely available for redistribution 